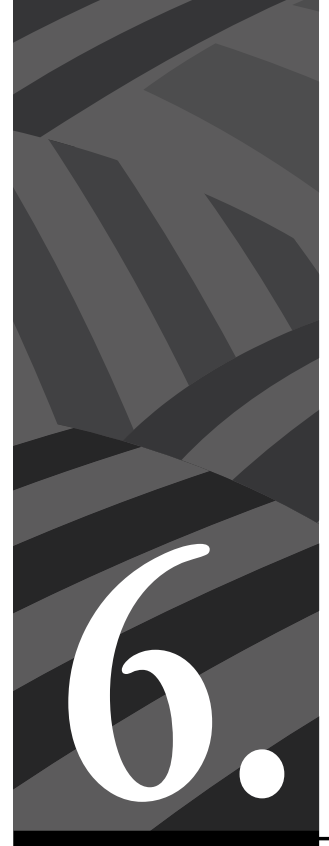

Conflictos interétnicos en el Caribe Insular Colombiano 


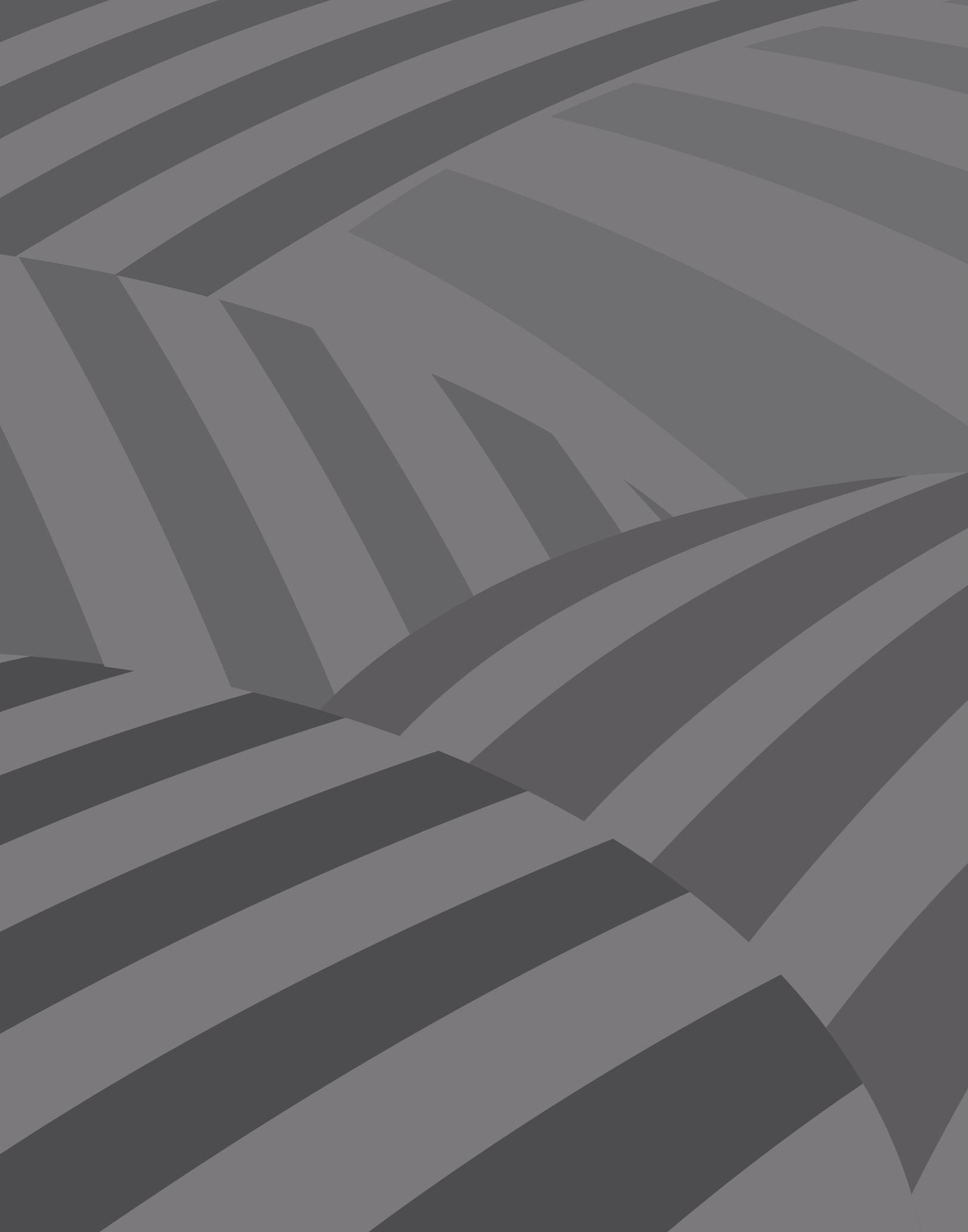




\section{Conflictos interétnicos en el Caribe Insular Colombiano*}

Por Inge Helena Valencia P. ${ }^{1}$

\section{Introducción}

Dos décadas después de que en muchos países de América Latina algunas poblaciones recibieran un reconocimiento especial en razón de su diferencia cultural asistimos a situaciones inéditas debido a la puesta en marcha de las políticas de reconocimiento de las constituciones multiculturales. Para el caso colombiano, este reconocimiento se configuró bajo el modelo andino para las poblaciones indígenas, (reconocimiento de una autoridad propia, el cabildo, asentada en un territorio cerrado, el resguardo) y para las poblaciones negras o afrodescendientes bajo el modelo propuesto por la Ley 70 de 1993 o Ley de Comunidades Negras que permitió la titulación colectiva de algunos territorios, sobre todo, en contextos rurales de la Cuenca del Pacífico.

El reconocimiento otorgado, si bien significa una ganancia, también ha acarreado la generación de conflictos en ciertos lugares y relaciones donde antes estas situaciones no se presentaban. El privilegiar a ciertas poblaciones y a otras no o el que algunos grupos utilicen la reafirmación de la autoctonía y la ancestralidad como elemento legítimo para el acceso a derechos diferenciales son argumentos que han debilitado relaciones sociales de convivencia entre grupos diferentes. Lo anterior ha

Artículo recibido en julio de 2015

Artículo aprobado en noviembre de 2015

Phd Universidad Icesi. Contacto: ihvalencia@icesi.edu.co 
tenido como consecuencia la generación de conflictos que se esparcen por todo el territorio colombiano.

El caso del archipiélago de San Andrés, Providencia y Santa Catalina brilla por su complejidad. Las islas de San Andrés, Providencia y Santa Catalina son las principales del archipiélago, que pertenece a Colombia y está ubicado en las inmediaciones de la región del Caribe occidental, a mil kilómetros de la Costa norte Caribe colombiana y a doscientos veinte kilómetros de la Costa Caribe centroamericana. Allí, en un pequeño territorio archipiélago e insular de cincuenta kilómetros cuadrados, conviven varias poblaciones: una nativa, la isleña-raizal, reconocida como el grupo étnico del Archipiélago, una emigrada proveniente de Colombia continental y otra emigrada proveniente de países como Siria y Libano. Estas poblaciones en sus procesos de cohabitación han permitido la emergencia de formas de socialización donde el mundo anglófono y el hispanófono, el católico, el protestante y el islam (de manera más tangencial) se encuentran. La reforma multicultural propuesta por la Constitución colombiana de 1991 permitió a la población nativa, la isleña-raizal, ser reconocida jurídicamente como grupo étnico del Archipiélago. Este hecho estuvo acompañado por la elaboración de una jurisprudencia especial que permitió que el Archipiélago se rigiera por normas especiales respecto al control de la migración y la economía.

En esta coyuntura la población isleña-raizal, ante la falta de respuesta a sus reclamos políticos y territoriales, optó desde hace algunos años por autodenominarse como población indígena: una estrategia para conseguir la salvaguarda territorial y de los derechos especiales que le otorga el Estado a minorías étnicas. Sus reivindicaciones se han hecho de la mano de fuertes denuncias frente a la crisis que lleva arraigada varios años en el Archipiélago, y que se relaciona con aspectos como la reversión económica vivida desde hace veinte años, y otras situaciones conflictivas como la escasez de importantes recursos como el agua, la sobrepoblación y, más recientemente, la violencia asociada al narcotráfico. La adopción de mecanismos institucionales promovidos por las políticas 
multiculturalistas han desencadenado una serie de conflictos en donde afloran diversas formas de reconocimiento y asignación de identidades, que fracturan las relaciones sociales construidas históricamente. Estas situaciones profundizan un conflicto existente entre los pobladores nativos y aquellos emigrados provenientes de Colombia continental que llegaron a las islas desde mediados del siglo XX impulsados por las políticas integradoras del Estado colombiano.

Este artículo da cuenta de algunos de los impactos de las políticas multiculturales aplicadas al caso del archipiélago de San Andrés, Providencia y Santa Catalina, con el fin de evidenciar los conflictos generados por la entrada en marcha del reconocimiento multicultural de 1991. Así, se abordarán las implicaciones del reconocimiento multicultural a partir del proceso de etnización de la población raizal y la generación de dos conflictos: i) el que se refuerza con los migrantes continentales denominados “pañas”, y ii) el que se genera en la recreación de una identidad de corte étnico causante de rupturas al interior de esta misma población. Ello con el objetivo de hacer una lectura crítica a los más importantes avances e implicaciones generados por la implementación de las políticas multiculturalistas.

\section{Región Archipiélago}

En las islas donde existe una tradición de poblamiento con una alta movilidad habitan actualmente los isleños-raizales, descendientes de migrantes europeos y esclavizados africanos, asentados permanentemente desde finales del siglo XVIII. Esta población comparte un idioma (el creole y el inglés caribeño) y algunas otras tradiciones (como la religión bautista) con otros lugares del Caribe anglófono. También habitan allí personas llegadas desde Colombia continental procedentes, en su gran mayoría, de la Costa Caribe colombiana y de algunos otros lugares como el Valle del Cauca y Antioquia, comúnmente llamados pañas. Muchas de estas personas empezaron a llegar desde mediados del siglo XX atraídas por una búsqueda de mejores oportunidades de vida. También en el 
caso específico de la isla de San Andrés hay una migración extranjera de personas procedentes de Siria, Líbano, Turquía y Palestina, llamados localmente como turcos, quienes llegaron impulsados por iniciativas comerciales desde otros lugares del Caribe continental colombiano como Maicao o Barranquilla o directamente desde sus países de origen. Adicionalmente, hoy se habla de la existencia de otro grupo, los half \& half, mity mity o fifty-fifty, que corresponden a aquellos hijos e hijas de madre o padre extranjero o continental, y de madre o padre isleñoraizal, quienes son los mestizos en este contexto insular. Durante años, estos grupos han logrado cohabitar pese a diferencias étnicas y religiosas, pero en los últimos años las situaciones de enfrentamiento se han hecho comunes debido a la crisis económica, social y ambiental que lleva más de veinte y cinco años arraigada en las islas.

Las condiciones particulares de las islas —como la composición étnica y cultural de la población isleña-raizal y su desarrollo económico ligado a actividades como el comercio y el contrabando- generaron grandes desacuerdos frente al proyecto de nación colombiano. Recordemos que el Archipiélago, al estar ubicado en el corazón del Caribe occidental y estar habitado por un pueblo anglófono, en su mayoría negro y protestante, más cercano a las Antillas inglesas (como Jamaica o las islas Cayman) que a la Colombia continental, se convirtió en una región problemática de acuerdo con los cimientos centralistas andinos, blancos y católicos con los que se estaba construyendo la nación colombiana. A pesar de la adhesión voluntaria a la República de Colombia hecha por algunos pobladores en 1822, desde comienzos del siglo XX, el Estado colombiano buscó integrar el Archipiélago a través de un fuerte proceso de asimilación. Esta situación causó el establecimiento de una relación ambivalente y conflictiva entre los pobladores de las islas y el Estado colombiano, en la cual los isleños reclaman su presencia, al tiempo que rechazan lo proveniente de la Colombia continental (Pedraza, 1989, p.34). 
De hecho, tras la declaración del Archipiélago como intendencia en 1912, se comenzó a implantar una soberanía ideológica en aras de integrar las islas al territorio nacional y al imaginario de nación que se manejó desde el centro del país, situación que generó conflictos y, así mismo, reclamos y movilizaciones. El mecanismo idóneo para este propósito fue, en primer lugar, asumir la instalación de la escuela y, junto con ella, la iglesia católica y la enseñanza del idioma español. Para ello, se impuso a sus habitantes la religión católica, se prohibió el inglés como lengua en las escuelas e incluso se llegó a clausurar en la mitad del siglo varias iglesias bautistas, que se constituían como el eje socio-cultural y educativo del Archipiélago ${ }^{2}$. Tal situación se recrudeció con los cambios producidos con la declaratoria de San Andrés isla como Puerto Libre en el año de 1953, y posteriormente con el desarrollo del turismo como principal actividad económica. La declaratoria como Puerto Libre, además de buscar incorporar las islas al territorio colombiano, también estuvo inspirada en legalizar muchas de las actividades comerciales que allí se ejercían para facilitar el ingreso de mercancías “libres” al país y fortalecer su desarrollo económico a través del fomento a la industria turística.

En los últimos veinte años el Archipiélago ha cobrado bastante visibilidad en el contexto nacional, debido a varias razones. Primero por su relevancia geoestratégica, que le permite a Colombia tener límites fronterizos con más de diez países, y le otorga más de 250000 kilómetros de mar territorial. Esta gran extensión marítima se vio reducida con el

Desde el año de 1926 hasta 1975, la misión católica tuvo la responsabilidad de la educación en las islas. Durante todos estos años el discurso escolar estuvo entreverado con lo católico, por lo tanto se adelantó notablemente el proceso de nacionalización, dándose importantes pasos al impartir varios conceptos morales y sociales de la nación colombiana. La conversión a la fe católica llegó a ser requisito para ocupar cargos públicos y disfrutar de otros beneficios oficiales como el de recibir becas universitarias. Se llegó inclusive a cerrar colegios donde todavía estudiaban la gran mayoría de niños y jóvenes. En el año de 1943 se impone el español como lengua oficial del Archipiélago, prohibiendo el uso del inglés en los colegios y en los documentos públicos. (Clemente, 1991: 234 y Vollmer, 1997: 65). 
resultado del Fallo de la Corte Internacional de Justicia de La Haya, que en noviembre de 2012 se pronunció respecto al diferendo limítrofe entre Colombia y Nicaragua. El fallo dio por terminada la controversia territorial que comenzó en 1980 cuando Nicaragua declaró la nulidad del tratado Esguerra-Barcenas que establecía los límites entre ambos países e inició un proceso de demanda en la Corte Internacional de Justicia de la Haya que se materializó en 2001. A pesar de que la soberanía sobre las islas fue ratificada en 2007, Nicaragua continuó su proceso de demanda frente a los límites de mar territorial, que finalmente desembocaron en los resultados de 2012. El fallo fue recibido con gran preocupación en el país frente a la pérdida territorial y en las islas fue recibido por ciertos sectores de la población nativa, la isleña-raizal, como un gran descuido que pone de manifiesto la desatención que el Gobierno central le ha otorgado al Archipiélago. Esta situación contribuye a fortalecer la existencia de una relación conflictiva de larga duración que, desde comienzos del siglo XX, ha alimentado los sentimientos autonomistas por parte de ciertos sectores isleños que claman por mayores derechos (Valencia 2002; Guevara 2003).

\section{La génesis del conflicto entre pañas-continentales e isleños-raizales}

La implementación de las políticas de colombianización, fortalecidas con la figura de Puerto Libre, unida al aumento de la población por migración, llevó a una notable disminución de recursos y a la reducción de tierras en manos de la población isleña. La irrupción de actividades comerciales significó un gran cambio para el contexto del Archipiélago: una gran mayoría de personas isleñas raizales quedaron marginadas por no conocer las dinámicas del comercio y del turismo, otros abandonaron sus actividades productivas tradicionales como la agricultura y la pesca para dedicarse al comercio, y otros, al no tener cómo sostenerse o respondiendo a la presión de los llegaderos, vendieron sus tierras, con lo cual se inició un proceso de despojo. Estas situaciones, unidas a la cada vez menor posibilidad de decisión de los isleños-raizales sobre sus 
propios asuntos, llevaron al surgimiento de importantes conflictos entre pañas-continentales e isleños-raizales.

Poco a poco los conflictos por el acceso a la tierra, la presión sobre los recursos naturales y la poca participación que tuvo la población isleñaraizal en las actividades comerciales comenzaron a manifestarse y hacerse públicos, y se materializaron en diferentes situaciones. La primera es la idea que comenzó a rondar en los pobladores nativos, según la cual el impulso a la llegada de personas continentales era una estrategia del Estado colombiano para despojar de las islas a los isleños con el fin de instaurar la soberanía nacional. De este hecho es famoso el episodio, que muchas personas isleñas narran, sobre la existencia de un documento secreto elaborado por el Estado colombiano donde se hacen sugerencias para asegurar la integración vía la inmigración continental.

La segunda consiste en que la llegada de muchos de los migrantes continentales, al no ser planificada, aumentó la sensación de invasión y de despojo por parte de los isleños-raizales. Si bien las relaciones con los continentales existieron desde comienzos del siglo XX, fue sobre todo a partir de 1960 cuando se comenzaron a generar fuertes diferencias, debido al incremento demográfico que tuvieron las islas, especialmente San Andrés. En estos años fue común que muchas personas provenientes de Colombia continental viajaran en búsqueda de mejores condiciones de vida, por lo que esta oleada migracional significó también el aumento de la competencia por acceso a los recursos entre los isleños-raizales y los migrantes continentales. Aquí vale la pena resaltar que dentro de la población paña-continental también se fueron configurando diferencias de clase, que marcaron el desarrollo de los conflictos. Mientras hubo un sector que logró convertirse en dueño de los hoteles (muchos provenientes de Antioquia y Bogotá), hubo otro sector de población de origen más popular, proveniente de lugares de la Costa Caribe continental, que se vincularon a la construcción y a los servicios generales como camareros, aseadores, cocineros. Y fue sobre todo este sector el que se catalogó como culpable del detrimento de la situación socioeconómica y ambiental de las islas. 
En medio del conflicto que comenzaba a nacer, las diferencias entre isleños-raizales y pañas-continentales, unidas a la disputa por recursos económicos y ambientales, se tradujeron en la elaboración de una representación del emigrado como un agente invasivo, conflictivo, violento, ruidoso, que resolvía los conflictos a través de manifestaciones violentas y vivía en barrios subnormales. Fue así como los isleños raizales comenzaron a señalar a los pañas como los agentes invasores, utilizando denominaciones peyorativas como champetudos, sharkheads, chambacus, términos que hacían referencia a su origen distinto, pero sobre todo a lo que para los raizales era un comportamiento invasivo de parte de estos. Encontramos entonces que la construcción de la diferencia y del conflicto entre pañas y raizales, antes que darse bajo un discurso étnico, se hizo apelando a la diferencia entre nativos y emigrados, y a fuertes diferenciaciones de clase que encontraron eco en la búsqueda de culpables frente a la competencia por los recursos y al deterioro económico y ambiental.

Finalmente, la tercera situación que refuerza el conflicto entre isleñosraizales y pañas-continentales se relaciona con el proceso de reversión económica que vive la isla desde 1990. A comienzos de esta década, la situación de deterioro de la isla se agravó por la coyuntura político-económica que vivió Colombia en el momento. Por un lado, la apertura económica de principios de los años noventa eliminó casi todas las ventajas comparativas del Puerto Libre, con lo cual la economía de San Andrés y la calidad de vida de la población de las islas se vieron muy afectadas ${ }^{3}$. La bonanza y estabilidad económica que había sido vulnerada generó

Para dar una idea de la crisis económica, puede ser ilustrativo abordar los índices de desempleo para las islas en la década de 1990. Hasta comienzos de la década de los noventa los aumentos de la fuerza de trabajo eran en su mayoría adsorbidos por la demanda, por lo tanto las tasas de desempleo se mantuvieron bajas. La recesión económica que atravesó el país desde 1992 y que afecto al Archipiélago hizo que desde este año hasta 1999 la tasa de desempleo pasara de $2.5 \%$ a $10.9 \%$, si se incluyen en la estadística los funcionarios de la gobernación, en su mayoría raizales, que fueron despedidos con la reestructuración administrativa del departamento a finales de 1999 (Bernal y Quintero, 2002). 
un clima de crisis e inestabilidad. Como resultado, los incentivos para viajar a San Andrés a comprar artículos importados se perdieron y, aún peor para la isla, los costos de transporte y las economías de escala hicieron que a menudo los artículos extranjeros resultaran más económicos en el comercio formal del continente colombiano. Sin embargo, esa caída no reflejaba adecuadamente la magnitud de la crisis del modelo sanandresano, ya que con el fin del "turismo de compras" se pasó hacia un tipo de turistas con un poder de compra mucho más bajo, que llegaba para disfrutar del sol y las playas en paquetes todo incluido, a menudo con tarifas muy económicas, que no dejaban ningún tipo de reinversión en la isla (Meisel, 2009).

En el marco de la coyuntura de reversión económica, algunos de estos líderes isleños-raizales buscan mayor participación en la vida pública de las islas y crean algunas organizaciones desde donde se impulsa la lucha por la defensa de los derechos de la población isleña-raizal en el marco del multiculturalismo de Estado.

Los conflictos entonces comenzaron a hacerse visibles de diferente manera, ya no solo por la presencia de la iglesia católica o la irrupción del idioma español, sino porque cada vez más llegaban personas a hacer presión sobre los recursos y el territorio. Lo cierto es que este proceso de integración o "colombianizacion” para establecer soberanía por las vías de carácter ideológico, y la de integración económica vía modernización y desarrollo, recrudecieron las situaciones de conflicto en el Archipiélago y fortalecieron la confrontación entre algunos de sus pobladores y el Estado colombiano, situación que se materializó en reclamaciones y procesos de movilización y organización social tendientes a confrontar al Estado colombiano a partir de la denuncia a instancias nacionales e internacionales. 
Figura 1

Incremento de población archipiélago de San Andrés, Providencia y Santa Catalina

\begin{tabular}{|c|c|c|c|}
\hline Año & San Andrés & Providencia & Total \\
\hline 1973 & 20.362 & 2.627 & 22.989 \\
\hline 1999 & 53.159 & 4.165 & 57.324 \\
\hline $\mathbf{2 0 0 5}$ & 77.084 & $\mathbf{6 . 3 1 9}$ & $\mathbf{8 3 . 4 0 3}$ \\
\hline
\end{tabular}

Fuente: Datos Censos Oficiales DANE 2005- Colombia

\section{Acción colectiva en el Archipiélago}

Es medio de este contexto, a mediados de la década de 1960 y paralelo a uno de los primeros momentos de recesión que se viven en la isla, se conforma un movimiento que busca ser escuchado en diferentes espacios e instituciones internacionales con el objetivo de denunciar los procesos de invasión y despojo vividos por la población isleña-raizal. Aquí vale la pena señalar también que el discurso afroamericanista presente en muchos lugares del Caribe anglófono a partir de la década de 1960 permite que algunos líderes y notables elaboren sus ideas alrededor de la conciencia e identidad negra de la población isleña raizal y de la importancia de luchar frente a los mecanismos "opresores" del Estado colombiano. Es evidente que en la década de 1970 hasta el año 2000 la búsqueda de poder político por parte de estos líderes y sus organizaciones está asociada también a una pérdida del control sobre los recursos y la capacidad de toma de decisiones en el Archipiélago.

Para 1965, un memorial firmado por varios isleños es remitido a la Corona británica solicitando la soberanía de Inglaterra sobre las islas, reconociendo el legado inglés en el proceso de colonización. Posteriormente, en 1972, un grupo de isleños residentes en Nueva York, autodenominados Comité Pro-Independencia de San Andrés, eleva una petición a la comisión de descolonización de las Naciones Unidas para obtener su separación de Colombia bajo la forma de un Estado llamado 
Federal Republic of Old Providence. Este movimiento consigue hacer llegar a la Organización de Naciones Unidas un documento respaldado por más de diez mil firmas, donde se presenta el caso del pueblo isleño raizal como víctima del colonialismo - en este caso colombiano- y se propone la creación de un Estado autónomo, soberano e independiente. Este es uno de los momentos más significativos en la vida política de la isla, ya que estas reclamaciones construyeron el imaginario, sobre todo elaborado desde el continente, de que la gente de las islas se quería separar del Estado colombiano.

Para mediados de la década de 1980 surge una de las organizaciones políticas más renombradas del Archipiélago: Sons of the Soil que nace con el propósito de la defensa a la sostenibilidad ambiental y cultural del Archipiélago, y lucha por la preservación de la cultura de la población isleña-raizal. Sons of the Soil fue una de las primeras organizaciones isleñas-raizales que nació como movimiento político y que se dio a conocer en Colombia continental. Uno de los pilares ideológicos de esta organización fue el cuestionamiento de la degradación ambiental de la isla, a partir del progresivo aumento poblacional que se dio desde su declaratoria como Puerto Libre, y con los cambios que trajo el turismo. Además de denunciar los efectos de la industria turística, Sons of the Soil se proclama como una organización abanderada en la defensa a la identidad isleña. En su manifiesto de creación plantea la necesidad de luchar colectivamente para “[...] asegurar la pervivencia como pueblo, defender el derecho de los isleños a una vida digna en su patria, alcanzar el bienestar para cada hijo de la tierra sin destruir tierra, agua, ni aire” (Ratter, 2000, p.138). Quienes conformaron Sons of the Soil eran isleños que asumieron ser víctimas como consecuencia de los abruptos cambios vividos en el Archipiélago tras la declaratoria de Puerto Libre. Más tarde, Sons of the Soil se consideró como una de las organizaciones abanderadas con respecto a la defensa y necesidad de protección de la población isleña-raizal, y fueron ellos quienes plantearon la acepción del significado del sujeto "raizal”, en tanto hijo de la tierra, del territorio insular, denominación necesaria para diferenciarse de los continentales 
que llegaban a las islas. En este contexto los "hijos de la tierra” o los "sons of the soil" fueron considerados como una metáfora a las raíces isleñas, sustento de una idea de cultura que materializaba la preocupación por la defensa del propio territorio, la protección de la cultura y los derechos a la autonomía y a la autodeterminación del pueblo raizal.

Es importante mencionar que años después Sons of the Soil, junto a otras organizaciones del mismo corte, impulsan la creación del Estatuto Raizal ${ }^{4}$, como proyecto de ley presentado a la Corte Constitucional, en el que se solicita la protección de la identidad raizal a través de la implementación de medidas puntuales en distintos campos como el económico, el comercial, el ambiental, el educativo y el cultural. Este proceso, en el que los raizales reclaman la restitución de sus derechos será la piedra angular de lo que años después se materializará en el reconocimiento de los derechos en la carta multicultural y, por otro lado, será la apertura a la consolidación del denominado movimiento raizal. Además de Sons of the Soil, otras organizaciones de gran importancia son el Movimiento de Amplia Reivindicación (MAR) y el Movimiento Cívico Isleño, unas de las primeras organizaciones que abogarán por los derechos de la población isleña-raizal. El Movimiento de Amplia Reivindicación (MAR) surge de la inquietud de algunas personas que se encuentran estudiando en Bogotá y que al regresar pretenden formar un movimiento político para trabajar en pro del Archipiélago, rechazando la tradición bipartidista que hasta ahora había primado en el Archipiélago y en el resto del país.

El MAR nace como un partido independiente y, como las otras organizaciones de esta época, incorpora las reivindicaciones de defensa a la sostenibilidad de las islas en un primer momento. Con el tiempo, en la década de 1990, el MAR se consolida ya no solo como movimiento, sino

$4 \quad$ El Estatuto Raizal fue un proyecto de ley presentado por algunos sectores de la población isleña-raizal, donde se proponían algunas medidas para materializar la búsqueda de autonomía y autodeterminación para el Archipiélago. 
como partido político del Archipiélago. Entre sus aportes se destacan el recoger ciertas iniciativas que son llevadas a la Asamblea Nacional Constituyente y que tendrán como producto final la elaboración del Artículo 310 que define al Archipiélago como un departamento especial. Al final de la participación en la Asamblea Constituyente, se produjo un documento que condensaba las ideas de todos los participantes de las mesas de discusión constituyente, y que giraban en torno a cuatro ejes fundamentales para la isla.

Estas iniciativas que se fundamentaron en aspectos como el cambio de intendencia a departamento, el control a la migración, y el respeto a la identidad de la población isleña-raizal tuvieron varios resultados: además de la expedición del Artículo 310, se logró la elaboración del Decreto 2762 de 1991, que permitió la creación de la Oficina para el Control a la Circulación y Residencia en el Archipiélago (OCCRE). Como es posible apreciar, el MAR, como partido político, canalizó su discurso en reclamos hacia el Gobierno, hacia la falta de políticas claras con respecto al Archipiélago, hacia el diseño de planes alternativos frente a los estragos de la modernización acaecida con el Puerto Libre (Valencia 2002). Por otra parte, la irrupción del narcotráfico a comienzos de la década de 1990 generó una economía que, con la retirada de la isla de los mayores capos, acentuó la recesión. En efecto, el narcotráfico se constituyó como una alternativa económica que reemplazó la bonanza comercial de años anteriores y le inyectó a la economía local importantes capitales y condujo a su vez a una nueva oleada de colombianos continentales de bajos recursos, atraídos nuevamente por la actividad de la construcción y la ocupación informal. Por último, las políticas neoliberales que se aplicaron a lo largo de la última década provocaron importantes ajustes fiscales que redujeron drásticamente la burocracia estatal en el caso particular del Archipiélago. Esta situación tuvo como resultado el empobrecimiento acelerado y el descenso de la calidad de vida de toda la población, debido al desempleo generado por el desmonte del Puerto Libre. Como resultado de este proceso encontramos un acercamiento, así como una intensificación de los conflictos entre 
pañas-continentales e isleños-raizales que, unido a la degradación ambiental y económica de la isla, provocó la intensificación de muchos problemas en un complejo escenario de relacionamiento social.

El desplazamiento territorial y el hacinamiento progresivo que vivió la población isleña-raizal afianzaron las diferencias y permitieron que las reivindicaciones por la propiedad y la defensa del territorio se tradujeran en un discurso de defensa a la propia identidad, que planteó que las tradiciones anglófonas de la población isleña o la misma sostenibilidad ambiental de estas se habían deteriorado frente a lo que para ellos era la invasión continental. Estas situaciones fueron utilizadas por algunos sectores isleños-raizales como argumentos para comenzar a buscar espacios, interlocuciones y estrategias que permitieran asegurar la protección y defensa de la población isleña-raizal. De esta manera, en medio del proceso de reversión económica de la década de 1990, se consolida el conflicto entre pañas-continentales e isleños-raizales y se da inicio al proceso de etnización vivido por la población isleña-raizal.

\section{La apropiación del discurso étnico y la consolidación del movimiento raizal}

El intenso posicionamiento étnico y político que la población isleñaraizal comienza a tener desde 1990 está marcado por el contexto de recesión económica que viven las islas a partir de la apertura económica orientada durante el gobierno de Cesar Gaviria. Esta situación se presenta también a partir de la adopción de las políticas multiculturales propuestas por la Constitución de 1991, lo que permite inferir que el proceso de visibilización étnico-política de la población isleña raizal llega en un momento de reconocimiento de derechos, pero también de reversión y crisis económica que nunca antes se había vivido en el Archipiélago y que además, en una escala más grande, obedece al reacomodamiento del multiculturalismo en los Estados neoliberales en América Latina (Duarte, 2004, p.138). 
Muchas organizaciones raizales de corte étnico surgen en la década de 1990 bajo la coyuntura del giro multicultural realizado por el Estado colombiano. Estos procesos se apropian de este discurso para ganar mayor visibilidad y capacidad de interlocución. Esta década significa la masificación del giro etnicista, que además de las reivindicaciones sobre la autoctonía y ancestralidad de esta población, añadirá nuevos contenidos discursivos, sustentados en la utilización de denominaciones como la de "pueblo indígena” o la de "etnia anglo-afro-caribeña”. El uso de este discurso étnico, acompañado de diversas manifestaciones políticas, permite que poco a poco se consolide la existencia de un movimiento social que, al mismo tiempo que aboga por la lucha y defensa de los derechos de esta población, evidencia los desacuerdos dentro de la población isleña-raizal frente a la decisión de etnizarse.

Entre las organizaciones que emergen o se consolidan durante el periodo posconstitucional, vale la pena mencionar las siguientes: Archipiélago Movement for Ethnic Native Self Determination (AMEN-SD) ${ }^{5}$, dirigido por pastores protestantes; The Ketlena National Association (KETNA), que recogió los objetivos del antiguo Sons of the Soil; INFAUNAS, grupo de agricultores y pescadores que defienden la protección del medio ambiente; San Andres Island Solution (SAISOL) fundado por algunos estudiantes isleños-raizales de 1980, y otras organizaciones más pequeñas como Barrack New Face, y Cove Alliance.

La importancia de estas organizaciones sociales radica en que a través de ellas la situación de crisis del Archipiélago se da a conocer, al tiempo que son las encargadas de posicionar los reclamos de la población isleña-raizal en el marco de su reconocimiento como grupo étnico. A través de sus acciones, el discurso de la diferencia étnica de la población isleña raizal se masifica, aspecto que posibilita el surgimiento de

5 Valga resaltar la correspondencia entre las siglas de esta organización, AMEN-SD, con la palabra amen, propia del contexto bautista del Archipiélago. 
diferentes posturas, tanto de los isleños que comienzan a ver "renacer" su identidad, como de los continentales que comienzan a ver cómo cada vez es más recurrente que sean señalados como los culpables de la crisis que había llegado al Archipiélago. Si hubiera que determinar un momento donde este movimiento se afianza, se podría decir que fue en 1999 con el surgimiento de AMEN-SD. Esta organización, en cabeza de sus líderes, entre los que se destaca el rol de los pastores bautistas (que refuerzan el rol de la religión como institución fundamental en la organización social de los isleños-raizales), convoca a personas y organizaciones más pequeñas, para visibilizar la situación de las islas y dar comienzo a un proceso de lucha por la defensa de los derechos de la población isleña- raizal.

Fue así como las iglesias bautistas estuvieron fuertemente vinculadas al movimiento étnico de la mano de AMEN-SD. Entre las iglesias que se comprometen de manera más decidida con estas reivindicaciones sobresalen: Lynval \& Cove, Claymount, Emmanuel, Sound Bay, Mount Zion, Christian Mision, San Luis Christian Mision, Schooner Bight, entre otras. AMEN-SD ocupa por lo tanto un lugar destacado entre las organizaciones sociales, en la medida en que, como proceso de convergencia, trata de constituirse como la organización que plantea los lineamientos y directrices del movimiento raizal.

AMEN-SD surge como respuesta a una serie de amenazas anónimas que recibieron algunos pastores y líderes locales del sector de La Loma. Este hecho tiene por consecuencia la realización de una gran marcha que se realiza en julio de 1999 y que finaliza con el bloqueo del aeropuerto. Esta movilización fue acompañada de un pliego de peticiones en el cual se exigía: "[...] iniciar la investigación de las amenazas, asegurar el cumplimiento de las normas sobre el control a la residencia en las islas, y asegurar la participación de la población isleña-raizal en la toma de decisiones de carácter político y administrativo, hechos que debían materializarse en la emisión del Estatuto Raizal, entre otros puntos” (Castellanos, 2006, p.34). 
Dos años más tarde en junio de 2001, AMEN-SD lleva a cabo otra serie de protestas, ya que se consideraba que el Gobierno no había cumplido los acuerdos de 1999, lo cual motiva el bloqueo del muelle, que a su vez impidió el abastecimiento de gasolina y la entrada de alimentos a la isla durante una semana. Al año siguiente, en abril de 2002 algunos grupos de isleños-raizales bloquean la vía de acceso al basurero Magic Garden, protestando por la insalubridad y la carencia de manejo de residuos. Durante el desarrollo del bloqueo, Ralph Newball, gobernador isleño-raizal del Archipiélago, emite un decreto donde prohíbe la entrada de los camiones de basura y en el que se niega a utilizar la fuerza pública para disolver a los manifestantes. Para la Procuraduría General de la Nación, estos hechos significan apoyar al bloqueo, por lo que esta institución abre un proceso disciplinario al gobernador que termina con su destitución. Para sectores isleños-raizales, la destitución de Ralph Newball es tomada como una clara confrontación de parte del Estado colombiano sobre la población isleña-raizal, lo cual termina en fuertes protestas y confrontaciones, en el marco de las elecciones presidenciales de 2002. Los choques que se producen llevan a la población isleñaraizal a interponer una denuncia pública ante la ONU, que cuenta con la participación de uno de sus relatores para los derechos humanos y que contribuye a visibilizar la situación de crisis y tensión social que se vive para ese momento.

A esta situación se adicionan otros hechos políticos importantes realizados por estas organizaciones, como la demanda interpuesta frente a la Comisión Interamericana de Derechos Humanos de la OEA en el 2005, a través de la cual se denunció la situación de crisis, exclusión y subordinación a que estaba sometida la población isleña- raizal. En 2007 también se realiza otra importante marcha contra el colonialismo colombiano, unos días antes de que el presidente Álvaro Uribe llevara al Archipiélago un desfile militar dirigido a conmemorar la Independencia de Colombia, como un acto de soberanía frente a las demandas limítrofes que Nicaragua adelantaba en la Corte Internacional de Justicia en La Haya. 
Los líderes del movimiento raizal coinciden en que las acciones colectivas se realizan para llamar la atención del Estado, y aunque en un comienzo tenían la intención de solucionar aspectos de primera necesidad para las islas, posteriormente discursos como el derecho a la autonomía, a la autodeterminación, y la protección a sus particularidades culturales comienzan a tener cada vez más importancia. Sin embargo, el hecho de que este movimiento en algún momento esté motivado por la idea de que la situación de crisis del Archipiélago se relaciona con el argumento de la llegada de los continentales, y que, como tal, es necesario impulsar su salida, ocasiona algunas críticas al interior de la sociedad insular. Más adelante veremos cómo con el transcurso de los años este argumento encuentra algunas resistencias al interior de la misma comunidad y de los pobladores de las islas.

Durante las movilizaciones de finales de la década de 1990 es importante remarcar el rol jugado por los pastores de las iglesias bautistas en los procesos de movilización social, ya que algunas de las manifestaciones son lideradas por ellos. Relación que puede rastrearse desde finales del siglo XIX, momento en el que sobresale el papel de la iglesia bautista en la impartición de la educación, y la alfabetización de la gente isleña raizal. Más adelante veremos cómo a partir de la década de 1990, la importancia de esa iglesia aumenta como consecuencia de su papel en AMEN-SD. Sin embargo, es importante mencionar que la presencia de la iglesia bautista en la esfera política de la vida de las islas no puede ser leída como un hecho aislado o propuesto solamente a través del surgimiento de esta organización.

En este contexto, AMEN-SD juega un papel de coordinación entre las diferentes organizaciones para que no haya múltiples grupos orientados hacia un mismo campo. De acuerdo con algunos sus miembros, uno de los logros más significativos del grupo es la demanda ante la Comisión Interamericana de Derechos Humanos de la OEA. Para el 2004, AMEN-SD envía a algunos representantes a Washington para realizar una presentación de la demanda. En ella, los exponentes denuncian los atropellos cometidos por el Estado colombiano, entre los que destacan: 
[...] el fomento a la inmigración de colombianos continentales, los métodos impositivos de evangelización ejercidos por la misión católica, la cesión de las Corn Islands, la declaración del Puerto Libre, y la elaboración de un documento secreto del Estado colombiano en el cual se estimaba la eliminación de la diversidad cultural del Archipiélago como parte del plan de "colombianización". De acuerdo con los demandantes, este proceso ocasionó sobrepoblación, discriminación política, religiosa y en derechos de pesca, devastación ecológica, dominación cultural, caos social, dominación militar y policial, desplazamiento económico y transferencia arbitraria de la soberanía del Archipiélago (Guevara, 2005, p.53).

Debido al protagonismo obtenido por estas acciones colectivas realizadas a finales de la década de 1990, unido a la legitimidad del discurso multicultural ofrecido por la Constitución de 1991, las organizaciones o el llamado movimiento raizal se convierten en un importante generador de discursos y acciones encaminadas a reivindicar la defensa de la identidad isleña-raizal en términos etnicistas que reclaman su ancestralidad. Por esto es importante hacer énfasis en el hecho de que frente al conflicto generado por el proceso de colombianización, y como consecuencia de los constantes reclamos realizados al Estado colombiano en materia de Gobierno, el descontento se traduce en una apropiación del discurso étnico. Este discurso facilita la profundización de las luchas por la reivindicación de derechos y la búsqueda de una mayor acción política para las organizaciones sociales isleñas.

Pero después de este periodo de movilización alrededor del tema étnicopolítico, las reclamaciones y movilización política a través de acciones colectivas disminuyen, paralelo al aumento del escenario de violencia asociado al narcotráfico desarrollado entre 2008 y 2012. Esto se relaciona con el miedo a las dinámicas de la violencia que se toman el espacio público en las islas. Pero también con diferentes señalamientos que se le realizan al movimiento raizal, en particular a la organización AMEN$\mathrm{SD}$, de tener vínculos con el narcotráfico, a través de la recepción de dineros para el financiamiento de marchas y protestas ${ }^{6}$. Frente a esta

6 Para más información sobre la supuesta relación entre AMEN-SD y narcotráfico ver artículo del Espectador “Justicia indaga si narcos infiltraron protestas raizales”: 
situación los líderes y voceros del movimiento han sido enfáticos en rechazar las acusaciones, y, por el contrario, plantean que esta es una estrategia del Estado colombiano para deslegitimar sus reclamaciones. Como lo menciona uno de los líderes del movimiento en una entrevista realizada apara un medio de comunicación nacional: "Nosotros no recibimos financiamiento de ningún 'narco', de lo contrario tendríamos carros y casas. El objetivo del Estado ha sido ese como una estrategia para deslegitimar nuestros reclamos ligados a la autonomía” (El Espectador, diciembre 27, 2007).

A ello se suma que, con el resultado del fallo de la Haya en noviembre de 2012, algunas organizaciones sociales retoman los reclamos de inconformidad política frente al Estado colombiano. Así, el fallo nuevamente reactiva las reclamaciones de la autonomía por parte de un sector de la población isleña-raizal generando en su coyuntura nuevos episodios de movilización y que algunos líderes raizales emprendan un proceso de lobby internacional por las agencias intergubernamentales de las Naciones Unidas (Unesco, Alta Comisión de derechos Humanos y la Secretaría General) para buscar una reconsideración del resultado del fallo (Taylor, 2013). Es claro que actualmente estos reclamos alrededor de la autonomía son realizados solo por algunos líderes, y los reclamos y acciones colectivas ligados a los procesos de movilización política disminuyen frente al arraigo de la violencia asociada al narcotráfico que el Archipiélago enfrenta desde 2010. Además, las movilizaciones pasan por un estado de agotamiento dado el incumplimiento de acuerdos de parte del Estado, la falta de apoyo de la sociedad insular y una cierta reticencia a ciertos discursos de tendencia radical que solicita la expulsión de los ilegales (Avella 2013, p.35). Unido a este panorama de asesinatos, amenazas, y señalamientos, las luchas sobre la autonomía comienzan a ser confundidas con luchas separatistas que entran a tensionar mucho más el espacio político y social local.

http://www.elespectador.com/impreso/cuadernilloa/judicial/articuloimpresojusticia-indaga-si-narcos-infiltraron-protestas-raizal. 
De este proceso de adscripción étnica que la población isleña-raizal comienza a vivir se evidencian tres situaciones. Primero, el proceso de etnización emerge como estrategia para adquirir legitimidad en la lucha por la defensa de la identidad propia, y así lograr defender ciertos derechos culturales, económicos y políticos. Segundo, con ella se busca dar cuenta de la diferencia que la población isleña-raizal establece con los pañas-continentales y a su vez con el resto de la Nación colombiana, en aras de permanecer en las islas, ya que a partir de 1990 serán minoría dentro de su propio territorio. Las luchas han tenido por consecuencia que en la coyuntura del reconocimiento constitucional aparezcan diversas organizaciones de carácter cívico, religioso y ambiental que se adjudican la lucha por los derechos de esta población. Tercero, veremos que la implementación de estas políticas multiculturales ha contribuido a fracturar los procesos de convivencia entre la población isleña-raizal y la paña-continental, lo cual ha afectado los procesos de convivencia histórica que han existido en las islas.

Figura 2

Genealogía de la formación de acción colectiva y movimientos sociales en el Archipiélago

\begin{tabular}{|l|ll|}
\hline \multicolumn{1}{|c|}{ Período } & \multicolumn{1}{c|}{ Características } \\
\hline Colonia y naciente república & $\bullet \begin{array}{l}\text { Procesos emancipatorios, y rebeliones } \\
\text { de la población esclavizada de origen } \\
\text { africano. } \\
\text { Adhesión voluntaria a la república de } \\
\text { Colombia 1822. }\end{array}$ \\
\hline 1940 - 1950 & $\bullet \begin{array}{l}\text { Declaratoria de las islas como intendencia } \\
\text { (1912). } \\
\text { Liderazgos, intelectuales y política }\end{array}$ & $\begin{array}{l}\text { Liderazgos políticos con reivindicaciones } \\
\text { alrededor de la mejoría de la } \\
\text { administración estatal. } \\
\text { Francisco Newball en Search Light. }\end{array}$ \\
\hline
\end{tabular}




\begin{tabular}{|c|c|}
\hline $\begin{array}{l}1960 \text { - } 1970 \\
\text { De intelectuales a movimiento de } \\
\text { masas }\end{array}$ & $\begin{array}{l}\text { Articulación raza y clase. Luchas globales } \\
\text { antirracistas y por la defensa de los } \\
\text { derechos civiles provenientes de EE.UU y } \\
\text { Suráfrica. } \\
\text { - Reivindicaciones contra el colonialismo } \\
\text { Colombiano. } \\
\text { - Influencia de pastoral afroamericana. } \\
\text { - Federal Republic of Old Providence. }\end{array}$ \\
\hline $\begin{array}{l}1980-1990 \\
\text { Movimiento masas/organizaciones } \\
\text { de base }\end{array}$ & $\begin{array}{l}\text { Emergencia de organizaciones que } \\
\text { reivindican procesos por la defensa del } \\
\text { territorio, la sostenibilidad ambiental y la } \\
\text { identidad propia. } \\
\text { Reivindicaciones dentro del convenio } 169 \\
\text { OIT. } \\
\text { Emergencia del concepto de Raizal como } \\
\text { población Nativa de las islas Sons of the } \\
\text { Soil. }\end{array}$ \\
\hline $\begin{array}{l}1991-2000 \\
\text { Reconocimiento como grupo } \\
\text { étnico }\end{array}$ & $\begin{array}{l}\text { - } \\
\text { Reconocimiento derechos especiales } \\
\text { para el Archipiélago: Art. 310, Ley } 47 \text { de } \\
\text { 1993, Importancia reconocimiento como } \\
\text { población Afrocolombiana Ley } 70 \text { de } 1993 . \\
\text { - } \quad \text { Reivindicaciones sobre el derecho a la } \\
\text { autonomía y la autodeterminación. } \\
\text { - } \quad \text { Emergencia Movimiento Raizal asociado a } \\
\text { repertorios de acción colectiva. } \\
\text { Archipielago Movement for Self } \\
\text { Determination (AMEN-SD). }\end{array}$ \\
\hline $2000-2015$ & $\begin{array}{l}\text { - } \\
\text { económización de la crisis social y } \\
\text { - } \quad \text { Irrupción de la violencia asociada al } \\
\text { narcotráfico. } \\
\text { - } \quad \text { Perdida territorial debido al fallo de La } \\
\text { Haya. } \\
\text { - Atomización del mMovimiento Raizal }\end{array}$ \\
\hline
\end{tabular}

Fuente: Valencia 2008, 2011a, 2011b y 2013 


\section{Las fracturas políticas de la convivencia insular}

Las expresiones políticas de parte de la población isleña-raizal pueden considerarse como una manera de hacer frente al proceso de integración realizado por parte del Estado colombiano, pero también como una respuesta frente a la pérdida de poder por parte de las élites isleñasraizales. Pero también veremos como los discursos situados desde una reivindicación etnicista propia del giro multicultural, han contribuido a generar algunas fracturas en los procesos de convivencia del Archipiélago.

\section{Primera fractura: hegemonía política versus hegemonía ideológica}

Con la llegada de una nueva lógica económica impulsada desde el Puerto Libre, las élites isleñas pierden parte de su capital social al tener que desenvolverse en un contexto cada vez más mercantilizado, lo que tiene por consecuencia que algunas de estas familias e importantes personajes queden excluidas de las actividades comerciales y turísticas que se comienzan a impulsar. Muchos además no desean vincularse a ciertos tipos de trabajos que exigen bastante esfuerzo y poca remuneración, como aquel que el turismo y la industria hotelera comienzan a ofrecer por estar relacionados con trabajos de mucho esfuerzo, pues en el contexto insular tienen poco prestigio y reputación. Recordemos que la sociedad isleña, como sociedad colonial, estuvo dividida por mucho tiempo entre la élite, asociada a los antiguos dueños de cultivos, notables, alfabetizados y los sectores más populares, los llamados “otros”, descendientes de los antiguos esclavizados, que se dedicaban a los oficios que la élite no realizaba como la pesca, la agricultura o el trabajo de construcción.

No es de extrañar entonces que en este momento de algidez en el clima político del Archipiélago surjan los comités prodefensa o proindependencia posterior al Puerto Libre como espacios políticos donde las élites 
puedan expresar su descontento frente a la pérdida de su poder frente la hegemonía comercial que se instaura en las islas con las actividades comerciales impulsadas desde el continente. De esta manera, son aquellas familias de élite y sus hijos las que, al perder los privilegios económicos, buscan recuperar el poder a través de su vinculación al campo de la política formal, a través de la creación de organizaciones sociales y la consolidación del discurso de la defensa de la población isleña-raizal. Frente al poder económico perdido, las élites isleñas-raizales apelan a discursos como la secesión, la autonomía o la consolidación de una identidad étnica, para desde el campo de la política, comenzar a recuperar el poder perdido con la colombianización.

En estos últimos años en las que ha tomado fuerza el discurso multicultural, se ha hecho posible hablar de minorías étnicas. De este modo, no es gratuito que hoy las organizaciones del Archipiélago hablen del ser raizal, o establezcan denominaciones como "pueblo indígena raizal” o "etnia anglo africana”, cuando antes se hablaba de comunidad isleña o de los nativos isleños del Archipiélago. Con esto lo que se pretende es ejemplificar cómo la población isleña-raizal establece un discurso propio de identidad y desarrolla estrategias específicas para implementar su etnicidad, de acuerdo con las particularidades, políticas y económicas en que se ven sumergidas las islas.

Aquí es importante reflexionar sobre cómo estas diferentes posturas al interior del movimiento y de la población isleña-raizal pueden ser expresiones ideológicas distintas de un mismo fenómeno de etnización. Desde la perspectiva propuesta por Roberto Cardoso (1992, pp.76-78) una identidad étnica puede estar compuesta por ideologías étnicas distintas. Las ideologías étnicas son representaciones de las respectivas situaciones de contacto entre poblaciones, elaboradas por los grupos étnicos envueltos en una situación de encuentro continuo y sistemático. Estas ideologías se fundamentan sobre conjuntos de "auto definiciones” o de concepciones de "sí", en contraste con una concepción o definición de las otras poblaciones en conjunción. En consecuencia, 
el proceso de articulación social expresado en las relaciones interétnicas - generalmente vinculado a situaciones asimétricas en el marco de sistemas de estratificación y de dominación social- está encuadrado en un proceso más amplio que lo condiciona. En este sentido, la dimensión ideológica de la identidad, se articula con las condiciones de carácter económico, político y cultural que le impone su entorno global. Como consecuencia, desde la perspectiva de Cardoso, el planteamiento de una identidad étnica, y más ampliamente de una ideología étnica, al considerar a la primera en términos de una categoría ideológica surgida del contacto y de la interacción interétnica, no descarta su articulación con el contexto histórico-social en el cual el contacto se realiza, lo que implica necesariamente un análisis de las condiciones en que se da.

En esta misma dirección, de acuerdo con Andrés Serbín, el problema se plantea así mismo en otro plano que nos permite considerar a los grupos étnicos no solo como la expresión empírica de la identidad y de la ideología étnica, sino también como grupos de intereses que formulan a través de su ideología no solo formas de preservación y defensa de su identidad étnica, sino también estrategias de poder especificas orientadas al logro de objetivos particulares en el marco de un sistema económico y político más amplio, que con su dinámica rige, en mayor o menor medida, las relaciones interétnicas (Serbín, 1987, p.61).

Por lo tanto, el proceso de etnización que vive la población isleña-raizal se llena de contenido en medio del conflicto con los pañas-continentales, la competencia sobre los recursos territoriales y una historia de confrontación hacia el Estado colombiano. Cardoso plantea que la definición de la etnicidad, en términos de ideología étnica, posibilita concebirla tanto en función de un sistema de valores que valide la identidad étnica del grupo como en función de los intereses y las estrategias que se implemente para lograrlos. Estos intereses pueden ser de diverso orden como la preservación de su status ocupacional, de sus privilegios en el acceso a ciertos recursos económicos o institucionales. Pero, en principio, así sean explícitamente económicos, implican la formulación de una estrategia 
eminentemente política para lograrlos. Por eso, la consolidación del movimiento raizal y el proceso de etnización de la población isleña-raizal, no puede ser leído por fuera del contexto de reversión económica de 1990, y de las políticas de reconocimiento propuestas por el multiculturalismo de Estado implementado desde la Constitución de 1991.

Este hecho nos demuestra la fisura que emerge entre una hegemonía ideológica y una hegemonía política, ya que las organizaciones y las élites isleño-raizales han perdido la capacidad decisión en su propio territorio, que en el contexto actual permanece en los gremios económicos, los cuales en su gran mayoría se encuentran en manos de burguesías foráneas, principalmente antioqueños, y algunos extranjeros. Es a través de estas situaciones de diferencia y choque con el Estado colombiano que se ha configurado una disputa por el poder ideológico, frente a la desvinculación económica y la pérdida de la hegemonía política por parte de la población isleña-raizal.

\section{Segunda fractura: raizales etnicidados versus raizales colombianos}

En palabras de Juvencio Gallardo (2001), líder histórico de la isla, la utilización del discurso étnico para reformular los reclamos realizados en décadas anteriores, se legitima debido al desplazamiento territorial, cultural, económico y político sufrido por la población isleña originaria. Para él, la población isleña-raizal esta ad portas de un "etnocidio”, por lo cual es necesario asegurar a toda costa su protección. Desde este momento se comienza a apelar a la categoría de "indígenas”, en aras de reconocerse como pueblo originario, diferente del resto de pobladores del Archipiélago y del territorio colombiano, buscando tener un mayor impacto en sus revindicaciones.

De estas denuncias al choque cultural y la sobrepoblación hay una transición en torno a la constitución de una identidad étnica sustentada 
en la utilización de la noción de "pueblo indígena"; con ello se busca avanzar hacia los derechos a la libre determinación, a la autonomía territorial, y al libre desarrollo de acuerdo al reconocimiento, asegurado por el Convenio 169 de la OIT sobre Pueblos Indígenas y tribales, suscrito por Colombia en la Constitución de 1991.

El carácter de "pueblo indígena" sustentado por el convenio 169 de la OIT es una definición bastante amplia, y al ser una jurisprudencia internacional pensada para abordar un gran número de casos y contextos nacionales, permite que muchas minorías étnicas, entre ellas la población isleño-raizal, se acojan. También se apela a conceptos como "Nación”, que desde perspectivas como la propuesta por Will Kymlicka, en su "ciudadanía multicultural” (1994), hace referencia a la autonomía cultural y a la existencia de las naciones, como pueblos que residen en un territorio con anterioridad a la formación del respectivo Estado. La idea de denominarse como "pueblo" debe permitir a los raizales ser reconocidos como grupo distinto, el cual podría ejercer poder y autonomía sobre el territorio que habita. Así, el concepto de Nación es utilizado reiterativamente por parte de los mismos raizales para sustentar algunas de sus ideas:

El pueblo raizal constituye un verdadero grupo étnico ya que es el pueblo autóctono que se conformó en el Archipiélago y desarrollo su sociedad aquí. Aunque el pueblo raizal es recientemente comparado con los indígenas, era dueño en el pasado de todo el territorio, lo que le da derecho a decir que sus miembros son los pobladores autóctonos o indígenas del archipiélago. (...) De la misma forma el pueblo raizal constituye una nación y no solo porque son el pueblo original del archipiélago sino porque tienen una cultura propia y diferente y una lengua propia también (Testimonio de Juvencio Gallardo, miembro S.O.S. en Cuadernos del Caribe No.1, 200, p.47).

De esta definición como pueblo indígena llama también la atención la manera como se constituye el discurso etnicista, apelando a la necesi- 
dad de redefinir su particularidad étnica a partir de la memoria de la trata, pero con la peculiaridad de reivindicar el registro propio del Caribe anglófono que evidencia la relación entre el rol que jugó el imperio británico en la colonización de algunas islas del Caribe occidental. La reivindicación de esta memoria y herencia africana se realiza en un primer momento a partir de la influencia del discurso afroamericano, que en el Caribe anglófono tiene una importante propagación debido al rol desempeñado por las iglesias bautistas, que predominan en esta región.

Para el caso de la población isleña-raizal, algunas de las reivindicaciones realizadas en la década de 1960 o 1970, están influenciadas por el discurso afroamericano de lucha y defensa de los derechos civiles, que llega a las islas por vía de los intercambios históricos que existen entre las islas, el sur de EEUU y otros lugares del Caribe anglófono, pero sobre todo debido al rol desempeñado por los pastores bautistas que transitan a lo largo y ancho de esta región Así, algunas de las movilizaciones realizadas en la década de 1970 se basaron en estas ideas:

[...] a partir de la influencia del discurso de intelectuales como Marcus Garvey, Malcom X y Martín Luther King algunos pastores y personas tenían posibilidades de formarse y educarse en lugares donde tenían acceso a este tipo de discursos. En este contexto las ideas que planteaban la necesidad de la liberación o lucha contra la opresión se tradujeron en la fuerte confrontación ante el Estado colombiano” (Ramírez, 2002 en Cuadernos del Caribe no. 4, p. 75).

Este registro anglófono apela por lo general a una herencia británica, que se reconstruye desde mediados del siglo XX, con el fin de acrecentar o demostrar las diferencias con las tradiciones hispanófonas del Estado colombiano. Además, la memoria anglófona también se rescata a partir de la migración que se realiza desde otras islas del Caribe, como Jamaica y las islas Cayman. Es entonces bajo la continuidad de los movimientos poblacionales como se construyen los marcadores históricos de la identidad de estos caribeños isleños-raizales pertenecientes al 
Caribe anglófono. Una identidad mediada por los contactos marítimos, fruto de contactos y migraciones; es en este sentido, un proceso radicalmente diferente a las identidades constituidas por los pobladores de origen continental. Así, la reivindicación de la herencia afro comienza a estar presente en el Archipiélago, no a través del discurso étnico territorial de base, que apareció en Colombia desde finales de la década de 1980 (sustento del proceso que ve nacer la Ley 70 de 1993) sino a través de la influencia del discurso afroamericano proveniente del Caribe anglófono, en especial de lugares como Estados Unidos y Jamaica.

De manera complementaria, y de acuerdo con Guevara (2005, p. 75), la herencia africana se ve fortalecida por los andamiajes institucionales propuestos por el Estado a través de la Ley 70 de 1993, o Ley de comunidades negras donde se instaura una comisión consultiva departamental y la posibilidad de que miembros de las islas participaran en la Comisión Consultiva Nacional7 . En la comisión consultiva departamental participan treinta líderes de organizaciones de base de San Andrés y diez de Providencia, y en la Comisión Consultiva Nacional participan líderes que desde las islas se encuentran con otras poblaciones negras del país.

Esta comisión consultiva es creada por medio del Decreto 1371 de junio 30 de 1994, como instancia para el diálogo entre las poblaciones afrocolombianas y el Gobierno nacional, así como un mecanismo de difusión

La Ley 70 de 1993, además de otorgar el reconocimiento al derecho de la propiedad colectiva de los territorios en zonas de la Cuenca del Pacífico, planteó algunos "mecanismos para la protección y desarrollo de los derechos de las poblaciones afrocolombianas". Entre ellos se destaca el fortalecimiento a los procesos organizativos de las poblaciones y la creación de las Comisiones Consultivas, como espacios de participación y consulta, adscritas al Ministerio del Interior. En Colombia existe la Comisión Consultiva de Alto nivel, donde participan representantes de poblaciones afrocolombianas de los departamentos de Antioquia, Valle, Cauca, Chocó, Nariño, la Costa Caribe y el archipiélago de San Andrés, Providencia y Santa Catalina y las comisiones consultivas departamentales conformadas por miembros de organizaciones sociales de cada departamento (Ministerio del Interior, 2001). 
de información oficial hacia las comunidades negras y de interlocución con directivos del orden nacional. Con la participación de la población raizal en la comisión consultiva, se abre desde el Estado una instancia que la invita a definirse como población afrocolombiana, y afirmar su participación en el Estado colombiano a través de su reconocimiento como minoría étnica.

En este contexto es importante retomar a Frederik Barth (1976) quien enfatiza la importancia de la autoadscripción y de la adscripción por otros, en el proceso de delimitación de fronteras étnicas entre los grupos sociales en interacción. Este proceso de adscripción colectiva pero a la vez subjetiva es conceptualizado por Barth como "etnicidad". La etnicidad surge en el contacto e interacción de distintos grupos étnicos, lo que necesariamente afirma la existencia de escenarios de contacto y de fricción interétnica. Sin embargo, conviene preguntarse por lo que significa apelar a la etnicidad, en medio de un escenario de amplio contacto interétnico entre isleños-raizales y pañas-continentales, caracterizado por la competencia identitaria, por el acceso a recursos, y la legitimidad de la permanencia sobre el territorio insular. En el caso de la población isleña-raizal, quienes comienzan a reivindicar esta identidad étnica fundamentan sus discursos a partir de las diferencias que existen entre pañas-continentales e isleños-raizales, debido a las diferentes trayectorias existentes entre la población isleña-raizal como perteneciente al Caribe anglófono, y la paña-continental como proveniente de los procesos propios de Colombia continental.

Pero la utilización de una denominación como la de "pueblo indígena” y la reivindicación de una identidad de corte étnico son puntos de debate dentro de la misma población isleña-raizal, ya que algunos sectores no comparten el significado de esta denominación. Así, se genera una fractura dentro de la población isleña-raizal por dos razones. Primero porque recrear este tipo de identidad obliga a buscar orígenes ancestrales que precisamente los isleños-raizales no poseen por su particularidad histórica de múltiples orígenes propios de su condición 
"caribe" (Rivera, 2002, p.76). Segundo, porque la reivindicación etnicista niega toda una tradición de mestizaje e intercambios que todavía es perceptible en las islas. En la actualidad, por ejemplo, es muy difícil establecer quién es raizal y quién no lo es, debido al gran mestizaje que tenido lugar en las islas. A este respecto nos cuenta Silvio Casagrande, otro líder raizal y exgobernador de las islas, que se ha caracterizado por sus posturas más conciliadoras:

Por ningún motivo queremos ser considerados como población indígena debido que al igual que todas las otras islas del Caribe somos "clase social" conformada por las migraciones de diferentes conjuntos socioculturales provenientes de Inglaterra, España, África y Colombia, siendo su disposición consecuencia de los azares de la historia. El hecho de ser diferentes en el territorio Colombiano y de estar asentados en la isla por más de dos siglos, no nos convierte en una comunidad indígena de la Región Caribe, más bien nuestros ancestros son tan responsables como las otras comunidades que migraron hacia esta región que aprovecharon los recursos naturales de estas islas. Sin embargo, el hecho de ser colombianos con lengua, cultura y costumbres propias tenemos el derecho de ser protegidos por el gobierno nacional (Documento Personal, Julio 16 de 2001, Archivo Personal Silvio Casagrande, en Valencia, 2002, p. 45).

Es posible advertir en este testimonio que al mismo tiempo que se endurece la posición etnicista de corte esencialista, entre otros sectores de la misma población raizal se llama a la concertación. Las reivindicaciones que realiza este sector de la población isleña-raizal, más que enfocarse únicamente al respeto de la diferencia cultural, se concentran en la búsqueda de elementos comunes entre la población venida del continente y los isleño-raizales como pertenecientes al contexto del Caribe anglófono. Bajo esta misma orientación ideológica, se aboga por la búsqueda de soluciones concertadas o la elaboración de políticas públicas relacionadas con el bienestar para la totalidad de la sociedad insular. Entre estas iniciativas se destacan la promoción de políticas públicas con relación a la reubicación de habitantes, mejoras en la educación y 
generación de empleo, y más puntualmente exigencias al Gobierno central para que destine recursos económicos que garanticen el desarrollo y la equidad social en el Archipiélago. Estos sectores, si bien hacen referencia a la defensa de su particularidad cultural como isleños-raizales, también plantean la importancia de reconocerse como colombianos y de ser parte de una sociedad conformada por distintos grupos sociales.

Este sector de población raizal, de corte liberal, hace referencia a la condición caribeña de múltiples orígenes, como argumento para rechazar el origen primordial y puro que reivindican aquellos que se denominaban como pueblo indígena, visible por ejemplo en argumentos como el uso de la lengua:

Nos apartamos totalmente de la idea de que el idioma raizal sea llamado creole o criole. El idioma de las islas es el inglés, como lo es en todas las islas caribeñas que estuvieron sometidas al dominio inglés. El creole es un dialecto para la comunicación popular. La primera población organizada y establecida en las islas fue de ingleses, quienes posteriormente trajeron esclavos negros de otras islas del Caribe, especialmente de Jamaica. Esa es la raíz de nuestra cultura con todas sus expresiones. Un raizal de San Andrés que viaje a Jamaica, entiende y se hace entender perfectamente y según entendemos, allí no hay ninguna escuela de creole, sino algunos de los mejores colegios de inglés (Documento Personal, Junio 15 de 2000, Archivo Personal Silvio Casagrande en Valencia 2002, p.75).

Las diferencias entre uno y otro sector de la población raizal también se hacen evidentes con relación a las demandas que el pueblo indígena raizal propone sobre el derecho a la autonomía y autodeterminación. Ya que para estos sectores isleños-raizales, la autonomía está relacionada con un régimen de pertenencia mixta, que les permita mayor independencia del Estado colombiano para acceder de manera directa a los recursos de la descentralización. Este es un punto de gran debate, ya que mientras unos sectores plantean y diseñan el Estatuto Raizal como proyecto de ley que materializa la autonomía propuesta en el marco 
del reconocimiento, otros sectores lo rechazan por considerar que la propuesta del estatuto es sectaria e inconstitucional.

Las discusiones sobre la conveniencia de aceptar o rechazar una identidad étnica de corte esencialista, contribuye a generar una fractura entre los pobladores de las islas, tanto isleños-raizales como continentales e incluso entre la misma población isleña-raizal. A este respecto es importante mencionar que estas diferencias que emergen en los discursos promovidos por algunos líderes raizales, implican también el surgimiento de varias organizaciones que tienen un gran impacto en la manera de pensar y establecer la relación con el Estado colombiano, pero sobretodo con los migrantes continentales y las nuevas generaciones de estos pañas nacidos en el Archipiélago.

\section{Tercera fractura: la gubernamentalidad multicultural y el rol de la Oficina de Control a la Circulación y Residencia (OCCRE)}

Además del reconocimiento como grupo étnico de Archipiélago, la Constitución de 1991 permite que el Archipiélago cuente con un régimen jurídico especial para controlar su migración y asegurar su sostenibilidad, de acuerdo con su contexto insular.

El control de la migración como situación particular a las islas, y que no se da en ningún otro lugar de Colombia, comienza a hacerse a través de la creación OCCRE con el Decreto 2762 de $1991^{8}$, oficina destinada a

8 La OCCRE en el Archipiélago surge a partir del decreto 2762 de 1991, "Por medio del cual se adoptan medidas para controlar la densidad poblacional en el departamento Archipiélago de San Andrés, Providencia y Santa Catalina”, reglamentación que surge a partir de la alta densidad poblacional que presenta la isla de San Andrés, y que establece ciertas diferenciaciones con relación a los derechos de residencia, en pos de "proteger" la subsistencia de la población nativa del archipiélago. 
restringir la migración en aras de proteger la identidad de la población isleña-raizal. Con el surgimiento de la OCCRE, el derecho de habitar en el Archipiélago se define a través del nacimiento en las islas, y se establece un criterio de diferenciación entre isleños-raizales y "otros". Con ello se inicia un proceso de clasificación de los pobladores, de esta manera son reconocidos como raizales los hijos de padres nativos y quienes puedan demostrar tres generaciones de filiación raizal a pesar de haber nacido en otro lugar. Como residentes se reconoce a quienes nacen en las islas o justifiquen la residencia por más de tres años consecutivos antes de que se expidiera el decreto.

Quienes no pueden demostrar este tiempo de permanencia quedan sometidos a la condición de ilegales, y en caso extremo se ven en la obligación de abandonar el Archipiélago, si no pueden legalizar su situación. Esta catalogación hace emerger de parte de sectores radicales de la población isleña-raizal posturas que solicitan la reubicación de los ilegales, lo que profundiza el conflicto que ya existía entre pañas-continentales e isleños- raizales. A las personas no nacidas en las islas, y que por diferentes razones llegan a residir allí después de la creación de la oficina, se les reconoce como residentes temporales. Estas personas tienen derecho de permanencia en las islas, durante un tiempo limitado y estipulado de acuerdo con las tareas y funciones que estén desempeñando. La OCCRE como institución que garantiza el control migracional estipula que los que viajan a las islas como turistas tienen un tiempo limitado para su estancia, que no puede sobrepasar los seis meses en un año. Hasta hace unos años existían dos tarjetas que distinguían a raizales de los otros residentes, pero recientemente se unificó este documento en la Tarjeta de Residencia Permanente (OCCRE, 2005).

Como la OCCRE es el organismo estatal encargado de definir quiénes tienen derecho a vivir en las islas a través de esta clasificación, la definición del ser isleño-raizal se institucionaliza a través de una concepción de identidad o "nacionalidad", definida por la sangre y no por el lugar de nacimiento o la permanencia en el territorio. Esta concepción 
suscita muchos conflictos, ya que fijar el derecho por sangre va en contravía del contexto de poblamiento diaspórico de las islas.

Con esta reglamentación, la necesidad de aclarar quiénes pueden acceder al reconocimiento como isleño-raizal, se hace bastante complicado dado el contexto de mezcla que ha preponderado en el Archipiélago. Si en un comienzo la OCCRE esperaba hacer un control migratorio de los que llegaban a las islas, esta institución terminó por definir y fijar el carácter "étnico" de sus pobladores. Como era de esperarse esta clasificación de los pobladores genera varios conflictos. Primero, tanto la población isleña-raizal como la continental tienen que justificar su descendencia y su origen, lo que al interior de la población isleña-raizal genera muchas incomodidades, ya que estos debe acreditar y documentar su derecho a la residencia en la isla, a través de documentos y genealogías. Para lograr la emisión de las tarjetas, las personas deben escudriñar en sus historias familiares o apelar a expertos que se encargan de rastrear los lazos familiares y elaborar árboles genealógicos, situaciones que son interpretadas como un proceso de fiscalización y fuerte control por parte del Estado.

Por otra parte, en la población de origen continental la sensación de conflicto aumenta, ya que demostrar el derecho de permanencia en el territorio a través de la sangre se contrapone claramente a los procesos de migración que muchos de ellos han vivido. Los emigrados continentales, argumentan que ellos ya se han establecido en el Archipiélago, y que ya existe una primera generación de ellos nacidos en el Archipiélago, por lo que los argumentos de expulsión no son fáciles de aceptar. Si bien la sobrepoblación es un fenómeno innegable, la reubicación y expulsión de un alto porcentaje de la población continental, no puede ser la única solución.

Muchos años antes de existir la OCCRE y antes de la llegada de la intensa migración continental, el ser isleño estaba dado por haber nacido en el territorio y compartir unas mismas formas de vida. Pero 
con esta nueva definición se genera una fractura, no solo porque la OCCRE formaliza los criterios de diferencia entre pañas-continentales e isleños-raizales, sino porque en la definición de una identidad a partir de una genealogía “pura”, los hijos de uniones interétnicas, deben entrar en una negociación constante para recibir su definición identitaria. La OCCRE establece que isleños-raizales serán aquellos individuos que puedan demostrar ser descendientes de familias que por más de tres generaciones han permanecido en el Archipiélago. Así un hijo de una unión interétnica, a pesar de considerarse como isleño-raizal y compartir la lengua y la cultura isleñas, solo es reconocido como "residente" por el OCCRE.

Esta situación generó profundas tensiones entre isleños-raizales y pañas-continentales, pero también entre los hijos de uniones interétnicas; en la medida que la definición institucional mucho más limitada de los isleños-raizales, excluyó a estos sujetos mestizos o fifty-fifty de la etnicidad raizal. Es muy importante resaltar que la definición de la OCCRE, no corresponde ni siquiera con los criterios más ortodoxos de la etnicidad esencialista, ya que no reconoce la importancia de la autodefinición a través de los hábitos, sino que impone criterios “objetivos”, instalando la definición identitaria bajo parámetros biológicos de pureza consanguínea.

Finalmente, la OCCRE al ser la institución que debe plantear medidas para asegurar el control poblacional, recrudece el conflicto entre pañascontinentales e isleños-raizales: aquellos que no pueden justificar la permanencia en las islas de acuerdo con las categorías establecidas por la OCCRE, se convierten en residentes ilegales y se plantea la posibilidad de expulsarlos. En la historia reciente de las islas, existen personas que fueron expulsadas después de redadas y operativos realizados por la OCCRE, funcionarios estatales que debieron dejar el territorio porque sus permisos de residencia no fueron renovadas o personas a las que no se les permitió la entrada a las islas, ya que no cumplían con los requisitos que la oficina solicitaba. 
Por otro lado, cabe remarcar que toda esta regulación emerge a partir de la institucionalidad que brinda el Estado colombiano a partir del marco de reconocimiento multicultural implementado desde la década de 1990. Esta situación de conflictividad demuestra que en las modalidades de etnización contrastiva que vive la población isleña-raizal, el Estado juega un papel muy importante al crear un sistema que como la OCCRE agencia una ciudadanía expresada en derechos de residencia territorial. Situación que lleva al borde del conflicto social a poblaciones divididas entre un "nosotros-legalizado” y un "otro-ilegalizado” definido por lazos de consanguinidad validados en el tiempo de residencia de hasta tres generaciones hacia atrás.

Un aspecto a resaltar de esta situación es que las formas de regulación implementadas desde las políticas multiculturales nos demuestran como el reconocimiento configura una nueva gubernamentalidad como un dispositivo para el Gobierno de las poblaciones. Esta gubernamentalidad se configura bajo los criterios organizadores de la actual economía política mediada por la institucionalidad de la gobernanza multicultural, donde la diferencia étnica se vuelve fuente de acceso a derechos fundamentales haciendo que muchas de estas poblaciones finiquiten su proceso de integración con el Estado (Rojas 2011 y Valencia 2011).

\section{Reflexiones finales: ¿se refuerza un conflicto interétnico en el Archipiélago?}

De la apropiación del discurso étnico por parte de algunos sectores raizales hay una situación que vale la pena resaltar y es aquella que relaciona el reconocimiento étnico con la generación de conflictos y la fractura de tejido social al interior de la sociedad insular. Es decir, las situaciones de conflicto social entre las poblaciones legalizadas por los códigos multiculturales y aquellas declaradas ilegales bajo esta nueva normatividad. Estas situaciones, se han traducido en un recrudecimiento del conflicto entre pañas y raizales, pero también al interior de la misma población 
isleña-raizal, ya que quienes no comparten la utilización del discurso étnico, encuentran problemática la utilización del discurso etnicista y segregacionista.

Esta situación nos permite observar hasta qué punto, para el caso del Archipiélago, el giro multicultural paradójicamente se reafirma en tanta homogeneidad, unicidad espacial y grupal. Situación que no deja de ser problemática frente a poblaciones que como la isleña-raizal, posee formas disímiles y heterogéneas para comprender y vivir su identidad. La reflexión de la antropóloga Diana Bocarejo para el caso de la convivencia inter-étnica en la Sierra Nevada de Santa Marta, bien podría aplicarse al caso del Archipiélago de San Andrés y nos brinda una pista de un fenómeno más amplio, una grave fisura en el Estado multicultural colombiano que parece extenderse rápidamente: "La distopía, esa reproducción de un lenguaje binario y estático que perpetúa fronteras, así como la configuración de diferencias auténticas legitimadas por el único origen, generan dificultades para una sociedad que habita el itinerante mundo de la frontera” (Bocarejo, en Rivera 2012, p. 69).

Otra consecuencia de la etnización es que así como las organizaciones han tenido una gran producción discursiva en defensa de la identidad raizal, estas también se han encargado de reproducir las fracturas entre pañas y raizales. Desde este punto de vista, paradójicamente, el discurso de la "diferencia cultural", en un contexto de competencia por la representación política frente a un lejano y discontinuo poder nacional, ha producido un ambiente de conflicto y segregación cultural. Un efecto importante ha sido señalar a los pañas como "culpables”, viniendo a jugar el típico papel de "chivos expiatorios” descrito por Rene Girard (1986) para las situaciones de conflictividad social.

Desde este punto de vista podemos plantearnos que el conflicto puede desatarse a dos niveles: i) entre grupos excluyentes o con los cuales los límites de la socialización son más distantes, nivel donde podríamos ubicar la división inter-grupal entre "pañas” y "raizales”; y ii) entre 
los semejantes que comparten un mismo grupo de convivencia (viejos contra jóvenes, padres contra alumnos, hermanos entre hermanos). Así las cosas, cuando en una relación asimétrica como la que puede existir entre "raizales” y "pañas”, el Estado le dice por medio de su corpus legislativo a una de las partes: todos los ciudadanos son iguales ante la ley, pero en el contexto multicultural es deseable definirte en tanto población étnicamente diferenciada; y al mismo tiempo le dice: ¡no todos son iguales y no todos pueden definirse étnicamente! Es evidente que surge una contradicción. Por lo tanto emerge un caso de identidad y una rivalidad donde seguramente será inevitable que surja un conflicto producido por la esta rivalidad.

Situaciones de este tipo evidencian el deterioro de la convivencia entre poblaciones heterogéneas que hasta hace varios años había caracterizado al Archipiélago. Aquí vale la pena señalar que una cosa ha sido el conflicto establecido con el Estado colombiano, que se establece desde comienzos del siglo XX, y otra cosa ha sido la manera en que un conflicto o discurso de segregación se ha fijado recientemente en el espacio social de las islas. El problema de la ruptura de esta convivencia no solo se debe adjudicar a la manera como han actuado las organizaciones raizales, porque sus reivindicaciones y luchas han sido creadas como respuesta a un conflicto histórico de tipo político frente a relaciones típicamente coloniales con el continente. Sin embargo, en la actualidad, dicho conflicto es menos presente en comparación con las profundas asimetrías de clase social y de marginalización que han producido entre la población insular, el monopolio de las actividades comerciales y la apropiación de la mayoría de los recursos económicos, por elites foráneas, que excluyen tanto a la población isleña-raizal como a la pañacontinental.

Otra situación problemática que se vislumbra es que, para el caso raizal, el carácter híbrido y heterogéneo que está presente en su propia historia ha sido negado para responder a las demandas del multiculturalismo etnizado, lo cual necesariamente ha generado un proceso conflictivo 
dentro de estas mismas poblaciones. Primero porque da cuenta de lo difícil que resulta para la población isleña-raizal, el intentar construir una identidad de corte étnico, “[...] ya que en las islas, inscritas en el contexto Caribe, el surgimiento de las etnicidades es más conflictivo debido precisamente a la multiplicidad de referentes identitarios que van más allá de los límites étnicos” (Losonczy, 2002, p.236).

En el caso del archipiélago de San Andrés, Providencia y Santa Catalina, vemos como la etnicidad y la reivindicación de la autoctonía borran referentes multipolares y multiterritoriales que son constitutivos de una identidad híbrida propia del Caribe. Esta definición de la identidad Caribe se sustenta en intercambios, producto del encuentro de identidades de diáspora. En ella las poblaciones caribes han guardado una especie de patrón pluricultural, definido por la idea de pertenecer por origen a diversas culturas que no se pueden reducir ni al color de la piel ni a comportamientos particulares, pero que han quedado grabados en una memoria compartida. La de su pertenencia a un territorio marcado por poseer un poblamiento exógeno constituido a partir de la confluencia de distintas migraciones y tener una matriz étnica que se constituye a partir de orígenes distintos. Sin embargo, frente a una memoria común que propone esta forma de sociabilidad caribeña el reconocimiento multicultural a partir de la reivindicación esencial de la autoctonía, borra estos orígenes diversos haciendo que algunas poblaciones como la raizal se piense como pura, lo que ha tenido por efecto el recrudecimiento de un conflicto ya existente con la población paña continental. Además como lo vimos en el caso de la OCRRE, por ejemplo, la implementación de políticas multiculturalistas se ha concentrado en privilegiar la invención de la etnicidad desde un punto de vista esencial que refiere la esencialidad a una pureza no contaminada por el relacionamiento con el otro y que no profundiza en las formas de relacionamiento entre grupos, o la configuración de sociabilidades entre poblaciones que no se definen étnicamente.

Además, la construcción de esta frontera étnica, se ha hecho estableciendo un conflicto especular con la población paña-continental. La 
presencia continental así como las relaciones que se han establecido entre estos y la población raizal, están reconfigurando el escenario identitario contemporáneo de esta "región” insular. Hoy los hijos de uniones interétnicas conocidos como fifty fiftys, half and half o miti miti o los hijos de migrantes, que nacieron en el Archipiélago, y que no responden a la frontera establecida jurídicamente por el Estado, reclaman un lugar en el espacio socio-político y territorial del Archipiélago.

Hoy existe un ambiente menos convivencial en las islas, marcado por el recrudecimiento de las diferencias que ha surgido y se ha potencializado a partir del mismo reconocimiento constitucional, así como por la entrada en vigencia de un marcado discurso que defiende la particularidad social y cultural de la población isleña-raizal. En este marco de relaciones es evidente que los mecanismos bajo los que han operado las organizaciones sociales raizales no han sido los más apropiados para mejorar las condiciones y conflictos que existen en la isla, porque en el fondo existe y siempre ha existido una gran dificultad para aceptar una definición de identidad construida o impuesta por el Estado colombiano. De ahí que existe una gran dificultad para aceptar estas definiciones que se ha podido aplicar a los otros pueblos indígenas de Colombia. A diferencia de estas últimas, la población del Archipiélago en su cotidianidad continúa llamándose a sí misma como "isleña”, con la connotación hibrida y heterogénea que dicho término implica. Por lo tanto, la ruptura etnicista ha contribuido a borrar una historia de intercambio, que en medio de este panorama de crisis social ha comenzado a minar ese estado de convivencialidad, y que desafortunadamente ya ha desembocado en situaciones de violencia sobre las tierras insulares.

Finalmente vale la pena remarcar que en las dinámicas de los últimos veinte años se han dejado de lado otras variables para explicar la existencia de muchos de los problemas de las islas, como la existencia de clientelas, corrupción, y una profunda situación de desigualdad al interior del mismo Archipiélago. En este contexto no podemos limitarnos a leer el proceso de etnización de la población isleña-raizal y el conflicto que se genera con los "pañas", sin otras variables, como el acceso y 
monopolio de los recursos o las redes de estratificación en el espacio social insular. Con ello podemos inferir que “[...] el multiculturalismo sigue como una apuesta por la política cultural de la diferencia, sin tener en cuenta los problemas relativos a la diferencia y la desigualdad material” (Fraser, 1997; Reygadas, 2005), tan comunes en Latinoamérica, y en particular nuestro país, uno de los más desiguales del continente.

\section{Bibliografía}

Agudelo, C., Boidin, C., Sansone, L. (2009). Autour de l”Atlantique Noir”: Une poliphonie de perspectives. IHEAL Editions. Collection "Travaux et Mémoires” No. 81. Paris, Francia.

Avella, F. (2011). ). Conflictualidad Latente y Convivencia Abierta (El caso de San Andrés). En: Mosquera, C. (Ed). La Universidad piensa la paz. (pp 77 -94). Universidad Nacional de Colombia, Bogotá.

Barth, F. (1976). Los Grupos Étnicos y sus fronteras: La Organización Social de las Diferencias Culturales. México: Fondo de Cultura Económica.

Bernal, C., Quintero, P. (2002). Turismo y desarrollo sostenible: una perspectiva desde lo ambiental y lo económico para San Andrés Isla, Colombia. Tesis de grado. Maestría en estudios del Caribe. San Andrés Isla, Colombia: Universidad Nacional de Colombia sede Caribe.

Castellanos, O. (2006). Procesos participativos en el Caribe Insular. Tesis de grado. Maestría en Estudios del Caribe. San Andrés Isla, Colombia: Universidad Nacional de Colombia Sede Caribe.

Cardoso, R. (1992). Etnicidad y Estructura y Social. México. Ediciones de la Casa Chata.

Clemente, I. (1991). Educación, Política Educativa y Conflicto Político-Cultural en San Andrés y Providencia (1886-1980). Bogotá: Departamento de Historia Universidad de los Andes.

Cuadernos del Caribe. (2001, 2002). Voces de San Andrés. Crisis y Convivencia en un Territorio Insular. Instituto de Estudios Políticos y Relaciones Internacionales. San Andrés Isla, Colombia: Universidad Nacional de Colombia Sede Caribe. 
Cunin, E. (Ed.) (2008). Textos en diáspora: Una antología sobre afrodescendientes en América. Instituto Nacional de Antropología e Historia. Centro de estudios mexicanos y centroamericanos. Instituto Francés de estudios andinos. IRD. México

Duarte, C. (2004). El gatopardo étnico. DEA. Estudios de sociedades latinoamericanas. IHEAL Sorbonne-Nouvelle. Paris III.

Enciso, Patricia, [narradores raizales]. 2004. Los hilos que amarran nuestra historia: historia oral y memoria colectiva, herramientas para fortalecer la identidad y la convivencia interétnica en San Andrés, Providencia y Santa Catalina. Bogotá: Native Foundation for the Archipielago's |Sustainable Development y GTZ.

Fraser, N. (1997). La justicia social en la época de la política de la identidad: Redistribución, Reconocimiento y participación. Estudios ocasionales. Bogotá: Facultad de Derecho de la Universidad de los Andes.

García M. (2013). “Colombianizar a toda costa o ser raizal allende los mares”, en Cien días vistos por Cinep, $\mathrm{N}^{\circ}$ 77, diciembre 2012-febrero 2013.

Girard, René (1986). El chivo expiatorio. Editorial Anagrama.

Guevara, N. (2005). Entre Colombia y el Caribe: Movimiento Autonomista en San Andrés Isla. Departamento de Antropología. Universidad Nacional de Colombia. Sede Bogotá.

Hall, S. (1999). Identidad cultural y diáspora. En: Castro- Gómez, S., GuardiolaRivera, O., y Millán de Benavides, C (Ed). Pensar (en) los intersticios. Teoría y práctica de la crítica poscolonial. Bogotá, Centro Editorial Javeriano (CEJA), Instituto de Estudios Sociales y Culturales (PENSAR), Pontificia Universidad Javeriana.

Losonczy, A. (2002). De cimarrones a colonos y contrabandistas: figuras de movilidad transfronteriza en la zona dibullera del Caribe colombiano. En: Hoffman, O. (Ed) Afrodescendientes de las Américas. Trayectorias sociales e identitarias. Bogotá: Editorial Unibiblos, Universidad Nacional de Colombia - Instituto Colombiano de Antropología. Pp. 215-244.

Meisel, A. (2003). La continentalización de la isla de San Andrés, Colombia: Panyas, raizales y turismo 1953 -2003. Documentos de trabajo sobre economía regional. Centro de estudios económicos regionales. Banco de la república. 
OCCRE - Oficina de Control de Circulación y Residencia. s.f. OCCRE. Generando Calidad de vida para todos. http://www.sanandres.gov.co/paginas/ turismo/requisitos_tarjetas_occre.doc

Pedraza, Z. (1988). Soberanía y deterioro cultural en el Archipiélago de San Andrés y Providencia. Revista Sotavento, vol. 1, no.2, Pp. 16-32.

Reygadas, L. (2005). La desigualdad más allá del multiculturalismo. Siglo XXI Editores.

Ratter Beatte. 2001. Redes Caribes, San Andrés y Providencia y las Islas Cayman: entre la Integración Económica Mundial y la Autonomía Cultural Regional. Bogotá: Universidad Nacional de Colombia.

Ramirez, S., Restrepo, A. (2001). Cuadernos del Caribe No.2 Voces de San Andrés. Crisis y Convivencia en un Territorio Insular. IEPRI. Instituto de Estudios Caribeños. Universidad Nacional de Colombia.

Rivera, M. (2012). Tan solo deja la huella de tu piel sobre la arena. Providencia: más allá de la etnicidad y la biodiversidad una insularidad por asumir. Tesis de Grado. Maestría en Estudios del Culturales. Bogotá: Pontificia Universidad Javeriana.

Rivera, M. (2002). Old Providence: minoría no armonía. De la exclusión a la etnicidad. Tesis de Grado. Bogotá: Universidad de los Andes.

Rojas, A. (2011). Gobernarse en nombre de la cultura. Interculturalidad y educación para grupos étnicos en Colombia en Revista Colombiana de Antropología. Vol 47 (2) Julio-diciembre 2011 ICANH.

Sandner, G. (2003) Centroamérica y el Caribe occidental. Coyunturas, crisis y conflictos 1503-1984. Bogotá: Editorial Unibiblos.

Serbín, A. (1987). Etnicidad, Clase Nación en la Cultura Política del Caribe de Habla Inglesa. Caracas. Biblioteca de la Academia Nacional de Historia.

Taylor Sally. (2010). Los Half And Half de San Andrés. Los actores Invisibles entre la etnicidad y la ciudadanía multicultural. Tesis Magister en Estudios del Caribe. Universidad Nacional de Colombia, Sede Caribe.

Valencia, I. (2002). El Movimiento Raizal: Una Aproximación a la Identidad Raizal a través de sus expresiones Político-Organizativas. Tesis de grado. Bogotá: Universidad Nacional de Colombia. Bogotá. 
Valencia, I. H. (2008). "Identidades del Caribe insular colombiano: Otra mirada del caso isleño-raizal”. Revista CS, (2), pp. 51-73. Cali, Colombia: Universidad Icesi

Valencia, I. H. (2011a). "Lugares de las poblaciones negras en Colombia: la ausencia del afrocaribe insular”. En Revista CS, (7), pp. 309-350. Cali, Colombia: Universidad Icesi

Valencia, I. H. (2011b). "Impactos del reconocimiento multicultural en el Archipiélago de San Andrés, Providencia y Santa Catalina: entre la etnización y el conflicto social”. En Revista Colombiana de Antropología, 47(2), pp. 69-95

Valencia, I. H. (2015). "Multiculturalismo y seguridad fronteriza en el Archipiélago de San Andrés y Providencia”. En Análisis, 6. Bogotá D.C., Colombia: Friedrich Ebert Stiftung - Fescol.

Vollmer, L. (1997). Historia del Poblamiento del Archipiélago de San Andrés Providencia y Santa Catalina. San Andrés Isla: Ediciones Archipiélago. Fondo de Cultura.

Wilson, Peter J. 2004. Las Travesuras del Cangrejo. Un estudio de caso Caribe del conflicto entre reputación y respetabilidad. Bogotá: Editorial Unibiblos - Universidad Nacional de Colombia. 